\title{
Stand Device
}

National Cancer Institute

\section{Source}

National Cancer Institute. Stand Device. NCI Thesaurus. Code C50189.

A support device designed to hold an object. 